\title{
DEATH AND BEREAVEMENT ON THE INTERNET IN SWEDEN AND NORWAY
}

\author{
Anders Gustavsson
}

\begin{abstract}
Memorial websites on the Internet constitute a new form for expressing grief and for remembering deceased relatives and friends. In my sample of memorial websites, I have studied those that are open to the public. Such memorial sites have had an explosive development during the 2000s. The messages become a virtual, social meeting place by giving mourners an opportunity to express themselves and avoid remaining alone with their grief. In this study the all-inclusive issue has been how mourners express their emotions and concepts of belief regarding the deceased person. The question focused upon is the belief in something posthumously supernatural. Memorial sites on the Internet are also set up for dead pets. The boundary between humans and animals as spiritual beings is discussed in the study. In Norway the vision is primarily directed backwards, relating to traditions, and in Sweden forwards, in the direction of changes. In Sweden there is a greater tendency to adopt innovations and to leave the longstanding. This study can, in addition, play a part in the contemporary discussion about greater outspokenness concerning death, compared to the prevalent silence and taboos of the 1900s.
\end{abstract}

Keywords: grief, innovation, memorial websites, national comparison, tradition

\section{INTRODUCTION}

As a cultural historian and folklorist, I have carried out research on varying themes and perspectives concerning death and dying in Sweden and Norway. My first studies were done in the 1960s and the 1970s about social distinctions in old cemeteries and about older burial customs and their survival, as well as their respective disappearance. One study concerned the disappearance of a very ancient funerary ritual in which guests drank a glass of wine or, in Norway, beer, in memory of the deceased and as a gesture of farewell just before the coffin was taken to the burial (Gustavsson 1973). This study was part of a bigger project at the University of Lund, which concentrated on life cycle from birth until death in Sweden (Bringéus 1987). 
After the 1970s, I left the research field concerning death and dying for a long time. This theme was not any longer topical within cultural research discussions in Scandinavia - on the contrary, it was practically a taboo to study such a theme. I noted, however, that an observable change occurred in the 2000s. This is in line with what the Danish sociologist Michael Hviid Jacobsen has found within social science after the 1980s. Then themes around death and dying could be brought to the fore instead of the earlier tabooing (Hviid Jacobsen 2009). In this new research situation I returned to study death and dying in earlier times but with an emphasis on the 1990s and the 2000s (Döden 2009). The research perspectives have been concentrated on individual symbols, collective rituals and messages and beliefs expressed on the Internet. The first study dealt with symbols of gravestones in cemeteries in Norway and Sweden in the 1990s and onwards and was performed within the research project Symbols of Death, started in 2000. I was especially interested in the new expressions of individualism in cemeteries. Questions about the growing individualism instead of earlier collectivism became obvious in ethnological discussions (Gustavsson 2003).

The second study discussed collective rituals around sudden death in recent times and was worked out within a collaboration project by cultural historians at the University of Oslo, and was concerned with different perspectives on rituals (Ritualer 2006). The third and latest study deals with bereavement expressed on the memorial sites for dead humans and pets on the Internet. Emphasis is placed on the analysis of the contents of the messages which stress a perspective of faith. This study has been worked out within the interdisciplinary research network named Nordic Network of Thanatology (NNT), founded in 2010, and Belief Narrative Network within the global International Society for Folk Narrative Research (ISFNR) (www.isfnr.org). I summarised many of my studies on death, burials and bereavement from earlier times until recently in a publication in English, entitled Cultural Studies on Death and Dying in Scandinavia (Gustavsson 2011).

It became important to compare the situations and developments in Norway and Sweden, as beginning from 1997 I worked as a professor at the University of Oslo, Norway, instead of my earlier academic positions in Sweden, in the old universities in Lund and Uppsala. In the 1980s and 1990s I met renewed discussions about national characters both in Norway (Hodne 1994) and in Sweden (Arnstberg 1989; Daun 1989), but no national comparisons were made within ethnology and cultural history. However, I became interested in such comparisons, through which it may be easier to observe the characteristic traits between cultures and in this case national characters. From the end of the 1990s I worked within a Swedish-Norwegian border project under the title 
Cultural Encounters of the Borders (Danielsson \& Gustavsson 1999) and was able, through fieldworks with interviews and photographs from both sides of the border, to observe many differences between these two neighbouring countries, which I had not imagined earlier.

During the 2000s, research on the material obtained from the Internet began to attract attention in the cultural sciences. This is seen, inter alia, in the articles in the annual Ethnologia Scandinavica 2009, which is devoted to critical questions about the Internet as a research source. Also of interest is the anthology Digital Storytelling edited by Norwegian sociologist Knut Lundby in 2008. The term 'netnography' has been taken into use. Robert V. Kozinets has provided the following definition: "Netnography is participant-observational research based on online fieldwork. It uses computer-mediated communications as a source of data to arrive at the ethnographic understanding and representation of a cultural or communal phenomenon" (Kozinets 2010: 60). The International Society for Ethnology and Folklore (SIEF) published an anthology Shaping Virtual Lives in 2012 (Shaping 2012).

In this new research situation I decided to study memorial sites that I had observed on the Internet. This new medium affords undreamt of and hitherto quite unexploited opportunities for conducting cultural research by allowing access to the emotions, beliefs and experiences of present-day people. The memorial websites constitute a new form for expressing grief and for remembering deceased relatives and friends. The messages are expressed by individuals on their own PCs in the privacy of their homes.

Because the messages and the imaginary conversations are published on the Internet, they are also accessible to outsiders, both acquaintances and strangers, including scholars. In my sample of memorial websites, I have studied those that are open to the public. Because of ethical reasons, I have avoided the ones that are available only to a limited circle or for which the guest must log on. The new Internet media, including memorial websites, have led to wholly new perspectives on ethical questions about private and public spheres when compared to previously held opinions (Hannemyr 2009). The scholar would act unethically as a spy if he or she logged on and became a member of such closed sites merely to observe and record, not to contribute a personal message.

Respect for anonymity is vital, as I study persons who write messages without their being aware of being followed. Anonymity in this study is achieved by omitting the surnames of message writers in my text. Messages on memorial websites usually include a photograph of the deceased, often a whole series of photos taken during the life of the deceased. These I have chosen not to publish because this would make identification easier. What is essential is that the scholar consciously tries to avoid inflicting mental harm upon those who are being studied. 
As a cultural scholar, one cannot escape being affected psychologically when reading all the extremely sorrowful and emotional messages on memorial websites. The scholar's insight power and feelings of empathy are vital in familiarising them with and interpreting the experiences of those persons who share their often despairing emotions.

Conducting the study on a regional basis in Norway and Sweden has not been possible, because the residences of the deceased and the writers are seldom noted; nor has it been possible to gain any knowledge of the writers' social statuses.

Memorial sites have undergone an explosive development during the 2000s. In 2008 there were about 600 memorial websites in Sweden (Dagens Nyheter, October 6, 2008). My research deals with memorial websites that became available in Norway and Sweden during 2009 and 2010, with the most extensive material being found in Sweden. My aim is to compare the situation in these two countries. What differences and/or similarities can be noted on memorial sites? What can be the causes for these differences? Innovation acceptance is contrasted with the preservation of traditions.

The memorial websites were set up by people who had recently suffered extreme grief in their immediate relationships. ${ }^{1}$ Messages about one and the same deceased person can continue over several years in connection with, for example, birthdays, name days and anniversaries of the dead ones. Although I have read messages posted on a great number of memorial sites, this study is by no means quantitative. As the memorial websites are so new, it is not yet possible to study changes over time, but it may be possible through renewed studies later on in the future.

Those who post messages on memorial websites are for the most part women, often mothers or widows and sometimes sisters. What can be the cause of this gender difference? It may be that at times of crisis men have more difficulty in expressing their deep emotions in words, and instead they move away and take shelter behind their wives' or partners' backs.

These websites become a virtual, social meeting place, giving mourners an opportunity to express themselves and avoid remaining alone in their grief. A new social fellowship arises, which is neither restricted in terms of space nor related to previous contacts in one's life. This was not possible before the Internet time. Memorial websites help to keep the memory of the deceased alive and not to be easily forgotten. Close relatives in the state of mourning are thus clearly gratified when other people post messages and when they light symbolic candles without words in memory of the deceased. A number of newspaper stories mainly in Sweden but also in Norway are based on interviews about the value of memorial websites and blogs for the closest grieving relatives in 
their prolonged process of mourning. This is an obvious example of the media's increasing frankness about reporting on the very real and intimate aspects of death that strike individuals.

In my present study the all-inclusive issue is how mourners on the memorial websites express their emotions and concepts of belief regarding the deceased person. The question focused upon is the belief in something posthumously supernatural, and not primarily the rational expression of grief such as remembrance, loss and love. Do concepts of life after death exist and how are they expressed? What is the status of the deceased considered to be on the other side and is he or she accessible in any way for the mourners? Can the dead be aware of and perceive the messages that the living send to them? Is any form of dialogue possible with them? Can the living at a certain point in the future, after their own deaths, be reunited with their dead loved ones and friends?

Memorial sites on the Internet are also set up for dead pets (in my research cats), for their former owners to express beliefs about what happens to pets after they die. The fixing of the boundary between humans and animals as spiritual beings is discussed.

This study can, in addition, play a part in the contemporary discussion about greater outspokenness concerning death, compared to the prevalent silence and taboos of the 1900s. The general trend, remarked upon by Michael Hviid Jacobsen (2009), can have aided people in the extreme, without the need to confront other people in person.

\section{BEREAVEMENT EXPRESSED ON MEMORIAL WEBSITES FOR DECEASED PERSONS}

The concept that the deceased are somewhere in heaven is very common in the messages. There they can meet with others who have died and live together with them. In their messages in guest books, other mourners can express hopes that their various relatives will be able to meet one another even if they were not acquainted during their earthly lives. A new fellowship that is comprehended to be real and similar to earthly life is assumed to occur after death. The deceased are believed to be able to continue practising their activities in heaven. Doubt or absolute denial of any form of existence after death is extremely rare in the messages.

It is often thought that the deceased can be contacted by the living and that the latter can even communicate their messages to the deceased on a computer. The technical possibilities of this life are, in other words, transferable to the existence on the far side of death. When the deceased are in heaven, they both 


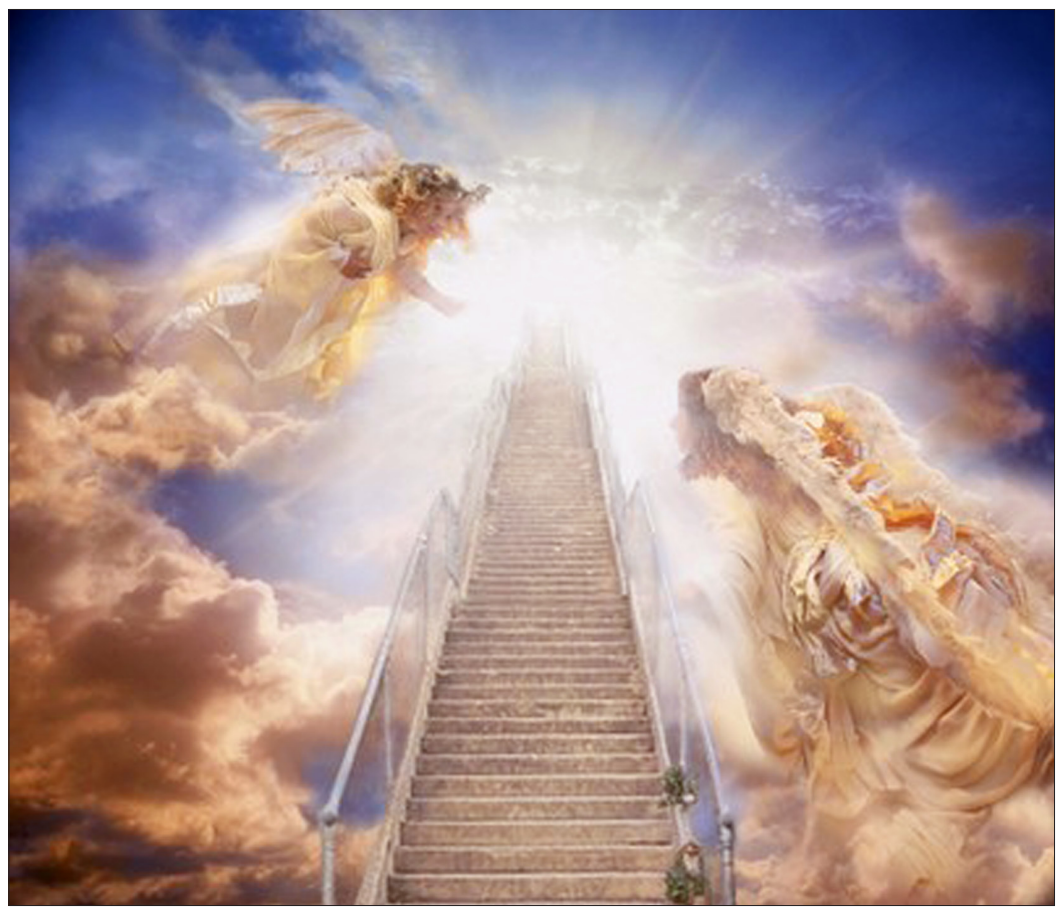

Figure 1. Angels guard the stairs that the dead use to climb up to heaven (www. tillminneav.se/showPage.php?id=.344, no longer available).

watch over and protect their friends and relatives. The conception of a reunion with the deceased sometime in the future often appears in the messages. A new existence and fellowship can begin that will never end. Finiteness is replaced by the everlasting, and joy is restored supremely. This is something to look forward to as a consolation in one's state of grief.

Belief in angels occurs in the messages very often. In order to enter their world, the deceased must climb an endless stairway that is depicted in some of the messages. The meeting with angels is described in a clearly positive context for the deceased. They can also speak in poetic form about how happy they are among angels. When Marcus suddenly died in 2002 at 20 years of age, his mother Mari-Anne wrote poems in which her son spoke to her from heaven. Because it is so good to be "where angels dwell", Marcus's mother believes that her son "will have a wonderful birthday party up there with the angels. I can see how you smile and laugh on your special day". This was written on Marcus's twenty-fifth birthday in 2007 (www.tillminneavmarcus.dinstudio.se).

It is in keeping with neo-religious New Age conceptions (Alver 1999) that angels are the beings mainly discussed as having a supernatural or divine 
character. Neither darkness nor punishment occurs after death, which is fully in line with present-day neo-religious movements.

A conception that is also used is that the deceased is a gift or a loan from God. God and Jesus are mentioned more often in Norwegian than in Swedish messages. This is especially noticeable in messages written by teenagers. When a Norwegian boy Trond was killed in a traffic accident at the age of 15, three girls from his class wrote: "God loves to pick flowers, and now he has picked the finest one, that's you, Trond”. Several other school friends mentioned God in their memorial messages about Trond.

A common concept is that children and young people become angels after death. This is in striking contrast to earlier beliefs in which the deceased were supposed to be souls, not angels. British sociologist Tony Walter has also found a similar change concerning beliefs in England (Walter 2011). The mothers of the dead ones call themselves 'Mothers of angels'. In addition, we can see the glorification of the deceased that is expressed by calling them the very best, finest or prettiest angels in heaven. The deceased can continue to spread joy and humour in heaven just as they had done on earth. For example, when Anders died suddenly at 45 years of age, his wife wrote:

All the angels are going to experience your good humour; the winds will spread the sound of angels laughing at your jokes.

(www.tillminneav.se/showPage.php?id=683)

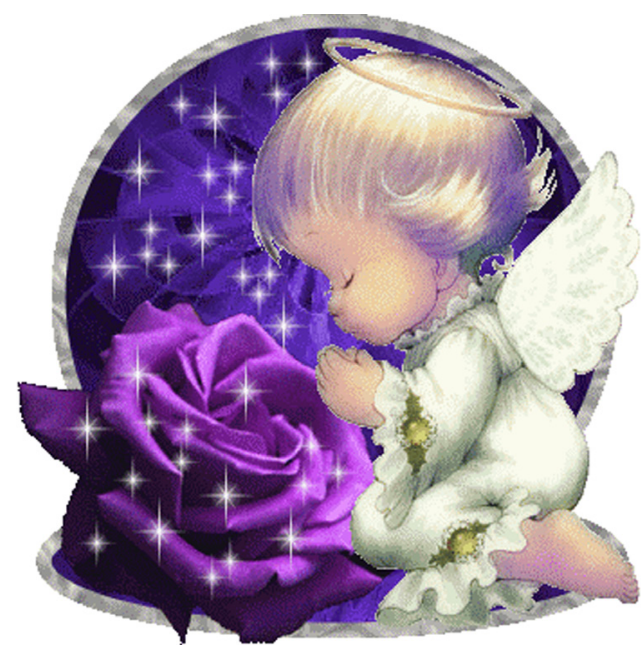

Figure 2. The mother of a deceased daughter has written: "Hugs from your beloved mother". The angel has both the halo and wings and may probably represent the daughter (www.tillminneav.se/showPage.php?id=34, no longer available). 
Memorial websites dedicated to the deceased generally contain far more traditional Christian conceptions in Norway than in Sweden. This concerns references to God and Jesus. In Sweden, we can observe more of a diffuse, general religiosity that reminds us of New Age modes of thought in which individuals and the brightness of a coming existence have a prominent position.

It can be difficult to give an explicit answer as to why former traditions associated with the deceased in general have a stronger position in Norway. A more obvious degree of secularisation clearly plays a certain role in Sweden. Another factor is individualism that is more evident in Sweden than in Norway. This is also visible in the choice of symbols on gravestones in Sweden and Norway in recent times (Gustavsson 2003). In Sweden there is often a tendency to regard what is new as being positive, to focus on the cheerful events emphasised by the media. The result can be that one covers over anything that is sorrowful.

When a child dies in the womb, it is quite usual for a mother in Sweden, but not in Norway, to write one or more messages on memorial websites. This usually results in several guest book messages from other mothers who have lost children in the same way. We often meet the declaration about the stillborn infant being an angel. This angel was in a hurry to return to heaven where the other angels dwelled. Angels are most often mentioned without God being named. A picture of a child with angel's wings is sometimes attached. These mothers call themselves 'Angel-mommies'. The infant's existence on the far side of death is seen as being a very real life. This is especially noticeable in messages that are written on delivery anniversaries. Parents can then imagine a birthday party in heaven and even send up a balloon. The mother of a girl called Adelsofie, who died in 2006, wrote:

Play with your angel friends and meet Mummy on the day when I come up to you! I'm looking forward to embracing you! [...] I do so hope that I will come to you in angel-land where time does not exist.

(www.adelsofie.webs.com/mammastankertiliver.htm, no longer available)

In some cases parents state that they believe or in other cases know that after their own deaths they will see their children again in some vague future.

It can be said that a final characteristic of the memorial websites for stillborn infants is that they really do not differ in any way from the ones relating to living children who have died. In their reactions of grief, parents do not differentiate between a living and a stillborn child. Children are seen as coming to a different and supernatural existence. They have been borrowed, whether they were born alive or died in the womb. The sorrow does not begin only after the death of a child born alive but concerns also a stillborn child.

I have conducted a special study of memorial websites relating to suicidal acts. Such sites contain numerous distinctive elements compared to websites 


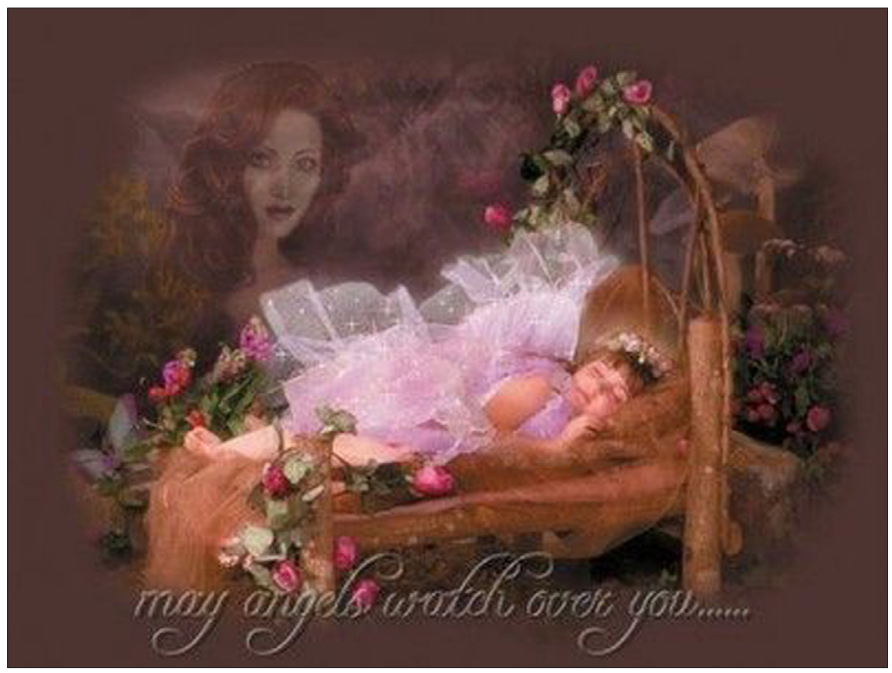

Figure 3. This picture was published on a memorial website for Ehline, who committed suicide in 2007, at the age of 31. The text reads: 'May angels watch over you' (www.minneavehline.blogg.se).

dedicated to other dead persons; also, clear differences between Norway and Sweden can be observed. These distinctive elements include criticism of the deceased, self-reproach among close relatives and friends, criticism of psychiatric treatment and repudiation of existing suicide guides. There are also some similarities between websites relating to suicides and those set up for other dead persons.

Despite their sorrow, sense of loss and shock, some Swedish statements and guest book messages show that close relatives find comfort in believing that the person who died through suicide could have come to a different existence after death. It is believed to be better than the life the deceased once had and consciously chose to leave. This new existence is, however, conceived of as being diffuse. These are not traditional religious conceptions. No thoughts of punishment after death are expressed. This corresponds fully with the neo-religious conceptions of 'the regained paradise' (Kraft 2011). In Sweden, the surviving relatives are also believed to be able to make contact with the deceased in the latter's new existence. Numerous messages mention the probability of a reunion between the surviving relatives and the deceased in some vague future. So, the sister of a young man called Pierre, who took his life in 2005 when 20 years of age, wrote:

I hope you will meet all of us, one after the other, with wide-open arms when it's our turn to come to the other side, because I know you are there somewhere and are waiting for us. (www.tillminneav.se) 
The deceased can also meet angels in the afterlife who care for them. They can as well be conceived of as being angels. This is more frequently spoken of than are conceptions of angels helping the deceased. A glorification of the deceased often occurs, in which the latter is seen as being the best angel that can be found.

In Sweden, the differences between suicides and other deaths have largely been wiped out. A certain standardisation has taken place, comparable to what has occurred in many other areas of social life. Equality, not differentiation, concerns all, according to the dominant political and media norms that have become increasingly strong. In order to achieve equality, former boundaries separating people must be broken down. As ideas of equal worth for all people have become the great ideal, this is also expressed on the memorial websites for the deceased. The belief in some diffuse existence after death, conceptions of angels and a conviction about the surviving relatives' reunion in some distant future with the person they have lost through suicide is consistent with what is expressed on the memorial websites set up for deceased persons in general. This same consistency is valid with regard to questions of glorification and honouring of the deceased.

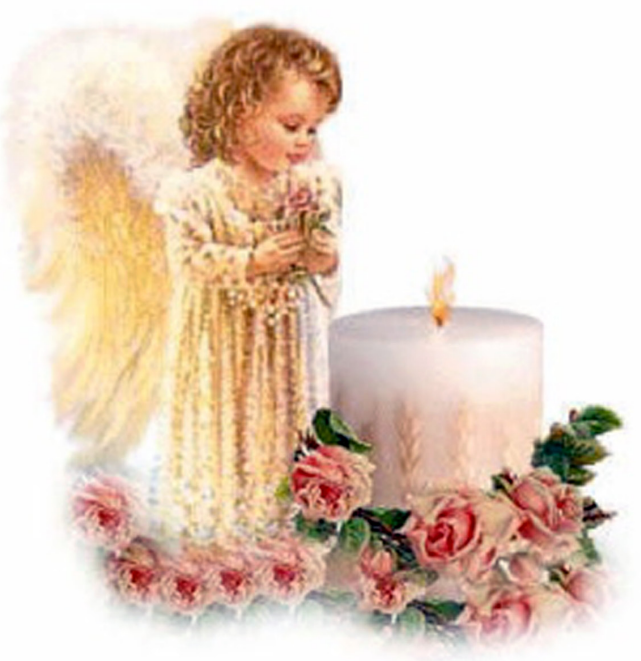

Figure 4. "Light a candle for my angel child," wrote Ehline's mother on October 31, 2009 (www.minneavehline.blogg.se). 
Norway is more restrained when it comes to expressing oneself about suicide, and the boundary between suicide and other deaths is marked in an entirely different manner. One does not encounter conceptions of an existence after death for those who have committed suicide. Glorification or expressions of honour are unthinkable, since this could lead to others being tempted to commit suicides. A so-called emotional contagion (sometimes known as "spillover effect") is to be hindered in every possible way. In Sweden, however, there is a clearly expressed conception about how messages on memorial websites can prevent suicide in that they show the unfortunate effects this has on the closest relatives. There are a number of visitors on Swedish guest books relating to suicide, who write that what they have read about suicides on the memorial websites encourages them not to take their own lives. They have gained a clear understanding of how much suffering a suicide causes to the closest relatives and friends.

The Norwegian material consisting of memorial websites about suicide is quantitatively scanty as compared to what exists in Sweden. This indicates that the former tabooing of suicide containing elements of shame is obviously greater in Norway. There also appears to be more keeping to former negative beliefs about those who commit suicide with reference to a coming afterlife. The stability of tradition is clearly more evident in Norway. Reticence concerned with speaking and writing about suicide is also noticeable in media presentations. In Sweden, too, the media was long restrained about mentioning personal names and writing articles about suicide. The death of the wrestler Mikael Ljungberg in 2004 resulted in a clearly observable change. It is after this period of time that more and more memorial websites have been established for persons who have committed suicide.

Even if equality and standardisation have become the ideal in Sweden, there are also certain differences between the websites set up for those who have committed suicide and those who have died in other ways. This is shown by the criticism, and not only glorification, that can be expressed about those who have taken their lives. The deceased cause extreme sorrow among their closest relatives and friends. For example, a young man named Janne took his own life when he and his girlfriend were 19 years of age. They had met in the evening, and had hugged and kissed each other. That same night he gassed himself to death, despite having said to his girlfriend, 'see you tomorrow'. She expressed her anger in the following way:

Oh, how mad I was at him. How could he do this to me? We had planned to sit together in a nursing home, drinking beer and smoking Marlboros. (www.metrobloggen.se/jsp/public/permalink.jsp?article=19.6367435) 
Criticism of this kind is even stronger in Norway than in Sweden. The words 'egoism' and 'cowardice' related to the deceased are conceptions that I have encountered on Internet websites only in Norway.

\section{BEREAVEMENT ON MEMORIAL WEBSITES FOR PETS}

Around 2000, scholarly interest arose among especially Norwegian ethnologists in studying the cultural connections between Man and animals, and a big research project was conceived on this topic in Oslo (Thorsen 2001). In that connection I chose to study memorial sites for dead pets, particularly cats. Using specific examples from animal graveyards, I found expressions of emotional intimacy between humans and their pets. Swedish memorial websites on the Internet for deceased pets began to appear at about the turn of the millennium, in 2000, with discussion forums and guest books. ${ }^{2}$ The number of such websites has increased noticeably since 2005. During the 2000s they also began to appear in Norway but not to the same extent as in Sweden. ${ }^{3}$ The people who contribute to these guest books are for the most part those who have had similar experiences of losing their cats. The guest books thus become a form of a meeting place where emotions and faith can be expressed and shared without the participants having had any previous familiarity with one another.

The issues considered in my study focus on the way in which pet owners express their emotions and their faith when confronted with the reality of the death of their animals. Have the memories and emotions regarding pets assumed forms that resemble the way in which close relatives mourn a person who has died? Can conceptions about the existence after death also be perceived in the case of animals and how are they expressed?

There are many cases in Sweden, and some also in Norway, of long descriptions of what the cat has meant to its owner in many different situations over the years. A photo or a drawing of the deceased cat is usually found in online messages. In Sweden there are some examples of such photos that have been replaced by a black cross exactly like those found in some obituary notices for humans. This never occurs in Norway. The glorification of the cat is evident in most cases. The cat has provided psychological support for the owners. The Swedish contributions describe such a degree of intimacy between the human and the cat that the latter assumes completely human characteristics.

Detailed descriptions of how the cat died are commonly included in the texts in both the Swedish and the Norwegian material. These descriptions obvi- 
ously constitute a way of adjusting to grief by allowing the owners to express their experiences of what has taken place. Intense and severe emotions are usually expressed especially in connection with the gruelling decision to have the veterinarian put the animal down. The psychological pain caused by the cat's sufferings has been very difficult to endure. In their grief, the owners in Sweden in some cases direct their accusations towards God. Such statements about God in relation to pets cannot be found in the Norwegian material. Here religion is kept separate from the death of an animal.

Generally speaking, it appears that pets are clearly integrated members in the families of those persons who choose to publish messages on the Internet. This applies to those who have the greatest need for expressing their grief and for sharing it with others. Grief and its accompanying emotions concerning the deceased pet have been provided with an opportunity to be expressed in the public sphere by making use of the Internet. In a developing modern society no need is felt for concealing grief from the others. It may even be less painful to write down one's experiences than to express them among one's nearest and dearest. The discussion forums on the Internet can in this way be of genuine assistance for surviving the lengthy process of mourning and for sharing it with others. In the midst of a difficult situation of grief, it may be of great help to realise that other people can publish contributions that will offer consolation and in which they can share their own previous experiences of endured grief. Traumatic emotions can be relieved when they surface through weeping or by written messages instead of being concealed. Answers may be received that can aid in the release of feelings in a grief-stricken situation.

A frequently recurring motif in Swedish statements is the concept of a future transcendent existence for the cat. The cat is thus believed to have acquired a new life in this feline heaven, which has a strong resemblance to its former living conditions on earth. Earthly life is in this way projected onto an assumed existence after death. Not only humans but also pets can be regarded as angels. The angel status can sometimes begin already during lifetime but manifests itself especially after death. The belief is very similar concerning dead humans and pets in Sweden. One expression that is used is that the deceased cat has passed on over the so-called 'rainbow bridge' to another world, called the Rainbow Country, where there are only positive emotions. In some cases a rainbow is depicted in the Internet contributions, as well as the 'rainbow bridge' that winds up towards the clouds. 


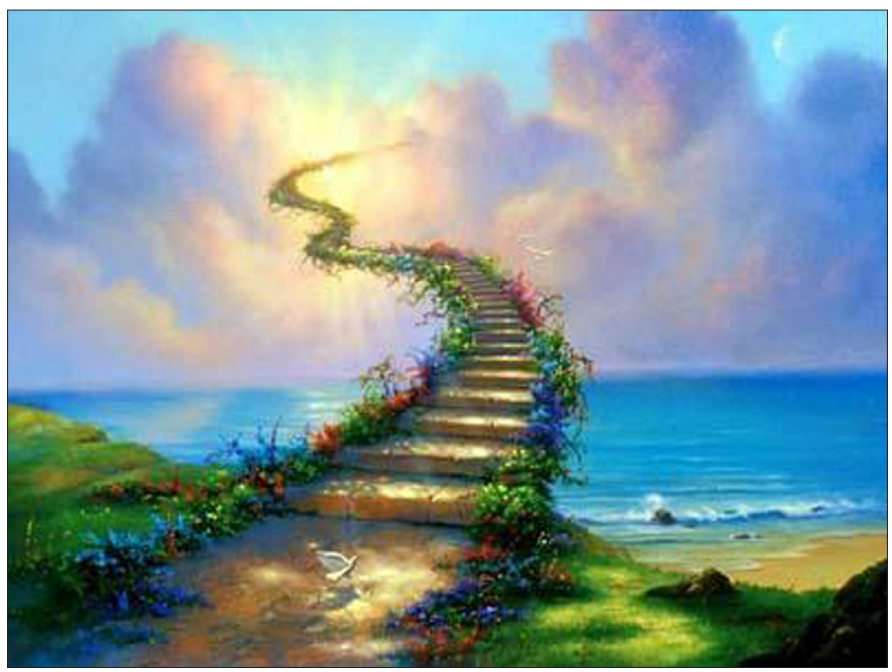

Figure 5. A place called Rainbow Bridge (www.acreswaycats.com/rainbowbridge.htm).

Belief in a future reunion between the cat and its owner on the far side of death can often be expressed. A belief of this kind can be linked to a Christian faith in some cases and not merely to a diffuse and general religiousness. There are also some instances in Sweden, as well as a few in Norway, of a cat having been ascribed an angelic character. The cat Mitzi is characterised as being an angel in the feline heaven. This demonstrates an obvious similarity to what has become common on memorial sites dedicated to human beings. In this regard, a clearly religious element has appeared in recent years, something that reminds one of the manifestations of angels related to neo-religious conceptions that have been linked to the recent deaths of young people in Sweden and, to some extent, also in Norway. A belief of this kind about deceased cats living on after death, experiencing continued contacts with their surviving owners and meeting them again after they themselves die, seems to be a new phenomenon that has manifested itself on the Internet. Norwegian Internet sites contain some examples concerning a fairly diffuse existence of the deceased cats after their death, but far from as many as in Sweden. The two Norwegian examples of cats as angels do not mention a possible future existence in heaven. In Norway, such expressions of faith are reserved solely for deceased people. The fixing of the boundary between humans and animals as spiritual beings is more pronounced in Norway than in Sweden. Norwegian contributions sometimes indicate a direct criticism towards 'humanlike characterisation'. Again, Norway has saved considerably more of the earlier tradition than Sweden. The concept of the 'rainbow bridge' does, however, occasionally surface in Norway. 
Swedish texts on the Internet consist of longer and more emotional messages than those I discovered in Norway. Conceptions of a feline heaven and angelic forms after death were in the focus in Sweden. This constitutes a manifest difference as compared to Norway. There the spiritual dimension in the form of pictorial symbols and texts is more pronounced on human graves than in Sweden (Gustavsson 2003). The situation between these two countries is entirely reversed regarding animal graves or animal memorial websites. In Sweden, the spiritual dimension after death is actually more pronounced with reference to animals than to humans. Changes in Sweden correspond with the preservation of traditions in Norway. Openness as regards death and the concept that one can converse with the deceased animal clearly appears to be on the increase in Sweden. Evidence has been found in Sweden, but not in Norway, that grief-stricken owners have conducted conversations with their dead cats on the Internet in the hope that the cats will be able to hear them communicate. The cat Isa that died in 2001, at the age of fifteen, received the following message from her owner:

I want you to know that I keep a picture of you on my bedside table and that I chat with you every evening and say good night; have you heard me? (www.katt.nu/kyrko-minnes5.htm)

One might actually speak of an anthropomorphic process. As a main result, I have found that the previously strict boundaries between humans and pets are increasingly in a state of flux in Sweden. Norwegian contributions, on the contrary, can sometimes indicate a direct criticism towards 'humanlike characterisation'.

\section{SOME CONCLUDING REMARKS}

In the present time, memorials on the Internet have given the scholars quite new possibilities to investigate the processes of bereavement concerning both deceased humans and pets. The changes can be very different in varying cultural but also national contexts. This is clearly visible in the comparison between Norway and Sweden. Tradition is the opposite of changes and this must be analysed in the light of different historical presumptions. In Norway the vision is primarily directed backwards, relating to traditions, and in Sweden forwards, in the direction of changes. Sweden features a marked tendency to adopt innovations and to leave the long-standing. One factor behind this is the stress on individuals in Sweden. The messages posted on the websites are both shorter and less emotional in Norway than in the case of their counterparts in Sweden, who observe more a diffuse, general religiosity that reminds us of 
New Age modes of thought, in which individuals and the brightness of a coming existence have a prominent position. In Sweden people tend to regard what is new as being positive, to focus on cheerful events. Life's darkest moments can be given a brighter shape. In this respect, Norway can be seen as being more realistic in its preservation of older traditions and in not merely rejecting life's darker sides without further discussion.

The Internet contributions studied here provide opportunities for establishing a number of fundamental ideas about contemporary humans. It is obvious that intense emotions need to find their expression in words and must not be suppressed within the thoughts of separate individuals. The process of grief must be allowed to be shared with others even if this is not done verbally within one's immediate circle of friends and relatives. It is not unproblematic to converse with just anyone about one's innermost feelings and traumatic experiences. Here the Internet can serve as a public sphere providing welcome relief when struggling to endure the difficulties of the grief process. Mourners can sit at their PCs in the privacy of their homes and express their innermost feelings and beliefs, and communicate them to a large number of mostly unknown people. The writers do not need to meet them physically, but can still receive responses and sympathy from those who have experienced similar difficult situations.

The mourner of a deceased pet maintains anonymity. This constitutes a difference compared to the memorial sites devoted to humans, in which the name of the deceased as well as the years of birth and death are stated. Despite the fact that anonymity is thus set aside, the mourners express themselves very openly. It may be easier to show grief openly for a close relative or friend than for a pet. In the social context, showing grief for the latter's death may be considered as less acceptable.

\section{NOTES}

1 The following are the homepages for mourners which I have studied in Sweden: www. bloggtoppen.se/tema/sorg/ (theme/sorrow); www.efterlevande.se/aktuell.html (the national league of widows and widowers), www.evigaminnen.se/minnessida/ (eternal memory); www.hem.passagen.se/anglaforum (angel forum); www.hem.passagen.se/anglaringen/ (angel ring); www.kanalen.org/barn-i-minne/sidor.html (children in memoriam); www.livetefterdoden, www.bloggagratis.se (life after death); www.metrobloggen. se (metro blog); www.minnesljus.se (memorial light); www.minneslunden.se (memorial grove); www.minnessidan.se (memorial site); www.mista.se (loss - begun in 2007); www.samsorg.se (SAMS cooperation for people in sorrow); www.smaanglar.org/ (little angels - organised by the parent association Little Angels); www.sorginfo.se (grief information - begun in 2005); www.tillminneav.se/showpage.phd?id (in memoriam, begun in 2006 and visited by more than one million people by 2010); www.vimil.se 
(those who have lost a loved one in the midst of life - begun in 2005); www.vsfb.se/ main/page (a non-profit parents' association for those who have lost a child).

The Norwegian memorial sites that I have studied are: www.englesiden.com (angels' site); www.etbarnforlite.no/Menysider/nyheter.htm (a child too few, set up by the association We Who Have a Child Too Few); www.forum.smartmamma.com/showthread. php (smart mama); www.hvilifred.no/index.php?id (rest in peace); www.minnelunden. no (the memorial grove).

${ }^{2}$ Http://hem.fyristorg.com/djurens_himmel (access restricted); www.katt.nu/kyrkominnes.htm.

3 Examples of Norwegian websites are www.hakrilas.no/tilminne, www.dyresonen.no (access restricted) and www.turtlecats-birma.net.

\section{INTERNET SOURCES}

www.acreswaycats.com/rainbowbridge.htm, last accessed on April 9, 2013

www.bloggtoppen.se/tema/sorg/, no longer available

www.dyresonen.no, access restricted

www.efterlevande.se/aktuell.html, no longer available

www.englesiden.com, last accessed on April 9, 2013

www.etbarnforlite.no/Menysider/nyheter.htm, last accessed on April 9, 2013

www.evigaminnen.se/minnessida/, last accessed on April 9, 2013

www.forum.smartmamma.com/showthread.php, no longer available

www.hakrilas.no, last accessed on April 9, 2013.

www.hem.fyristorg.com/djurens_himmel, no longer available

www.hem.passagen.se/anglaforum, last accessed on April 9, 2013

www.hem.passagen.se/anglaringen/, last accessed on April 9, 2013

www.hvilifred.no/index.php?id, last accessed on April 9, 2013.

www.isfnr.org, last accessed on April 9, 2013.

www.kanalen.org/barn-i-minne/sidor.html, no longer available

www.katt.nu/kyrko-minnes.htm, last accessed on April 9, 2013.

www.livetefterdoden.com, no longer available

www.bloggagratis.se, last accessed on April 9, 2013

www.metrobloggen.se, last accessed on April 9, 2013

www.minnelunden.no, last accessed on April 9, 2013

www.minnesljus.se, last accessed on April 9, 2013

www.minneslunden.se, last accessed on April 9, 2013

www.minnessidan.se, last accessed on April 9, 2013

www.mista.se, last accessed on April 9, 2013

www.samsorg.se, last accessed on April 9, 2013

www.smaanglar.org/, last accessed on April 9, 2013

www.sorginfo.se, last accessed on April 9, 2013

www.tillminneav.se, last accessed on April 9, 2013

www.turtlecats-birma.net, last accessed on April 9, 2013

www.vimil.se, last accessed on April 9, 2013

www.vsfb.se/main/page, last accessed on April 9, 2013 


\section{REFERENCES}

Alver, Bente Gullveig, 1999. Fra englevakt til englevinger. In: Bente Gullveig Alver \& Ingvild Sælid Gilhus \& Lisbeth Mikaelsson (eds.) Myte, magi og mirakel i møte med det moderne. Oslo: Pax forlag, pp. 183-199.

Arnstberg, Karl-Olov 1989. Svenskhet. Den kulturförnekande kulturen. Stockholm: Carlsson.

Bringéus, Nils-Arvid 1987. Livets högtider. Stockholm: LT.

Dagens Nyheter [newspaper], October 6, 2008.

Danielsson, Rolf \& Gustavsson, Anders (eds.) 1999. Gränsmöten. Strömstad: Strömstads Museums Förlag.

Daun, Åke 1989. Svensk mentalitet: Ett jämförande perspektiv. Stockholm: Rabén \& Sjögren.

Digital Storytelling, Mediatized Stories 2008. Ed. by Knut Lundby. New York: Peter Lang Publishing.

Döden 2009 = Anders Gustavsson (ed.) Döden speglad i aktuell kulturforskning. Uppsala: Kungl. Gustav Adolfs Akademien för svensk folkkultur.

Ethnologia Scandinavica 2009. Uppsala: Swedish Science Press.

Gustavsson, Anders 1973. Minnesdrickning vid begravning. Årsbok / Vetenskapssocieteten $i$ Lund.

Gustavsson, Anders, 2003. Gravstenar i Norge och Sverige som symboler för känslor, tankar och idéer $i$ vår egen tid. Oslo: Novus.

Gustavsson, Anders 2011. Cultural Studies on Death and Dying in Scandinavia. Oslo: Novus.

Hannemyr, Gisle 2009. Personvern i deltakerskapte, rike medier. In: Heidi Grande Røys (ed.) Delte meninger: om nettets sosiale side. Oslo: Universitetsforlaget, pp. 161-175.

Hodne, Bjarne 1994. Norsk nasjonalkultur: En kulturpolitisk oversikt. Oslo: Universitetsforlaget.

Hviid Jacobsen, Michael 2009. Den femte fase - med Philippe Ariès ind i det 21.århundrede. In: Anders Gustavsson (ed.) Döden speglad $i$ aktuell kulturforskning. Uppsala: Kungl. Gustav Adolfs Akademien för svensk folkkultur, pp. 15-40.

Kraft, Siv Ellen 2011. Hva er nyreligiøsitet. Oslo: Universitetsforlaget.

Kozinets, Robert V. 2010. Netnography: Doing Ethnographic Research Online. Los Angeles: Sage Publications.

Ritualer 2006 = Arne Bugge Amundsen \& Bjarne Hodne \& Ane Ohrvik (eds.) Ritualer. Kulturhistoriske studier. Oslo: Universitetsforlaget.

Shaping 2012 = Violetta Krawczyk-Wasilewska \& Theo Meder \& Andy Ross (eds.) Shaping Virtual Lives: Online Identities, Representations and Conducts. Łódź : Wydawn. Uniwersytetu Łódzkiego.

Thorsen, Liv Emma 2001. Hund! Fornuft og følelser. Oslo: Pax.

Walter Tony 2011. Angels not souls: Popular religion in the online mourning for British celebrity Jade Goody. Religion, Vol. 41 (1), pp. 29-51, http://dx.doi.org/10.1080/ $0048721 X .2011 .553138$. 